\title{
TESES DE DOUTORADO E DISSERTAÇÕES DE MESTRADO DEFENDIDAS
}

\author{
(Novembro de 2005 a Abril de 2006)
}

\section{Teses de Doutorado}

\section{Condicionantes geoambientais na evolução do relevo de um maciço costeiro}

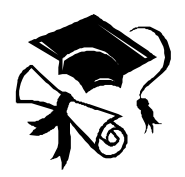

Antonio Celso de Oliveira Goulart

Orientador: Prof. Dr. Adilson Avansi de Abreu

Em Vitória (ES), as condições de uso da superfície do relevo em uma aglomeração urbana e as respostas da estrutura natural do relevo a essa intervenção instigam a análise do comportamento dinâmico das vertentes íngremes em morros de rochas cristalinas presentes na paisagem do Maciço Central.As áreas de encostas são transformadas em locais de ocupação urbana, muitas vezes em evidente condição de risco em virtude da notável instabilidade dos materiais da vertente, ora constituído por espessas camadas de solos, ora constituído por blocos rochosos com intensa rede de fraturas e diáclases.Esse cenário é afetado recorrentemente, desde as áreas localizadas nos topos desses morros até a base das encostas, por episódios de movimentação de material ao longo da superfície. Quando as encostas são ocupadas ocorrem alterações em série com possíveis conseqüências danosas do ponto de vista social e político-administrativo.Todo ano, durante o período de maior precipitação, ocorre um correspondente aumento da atividade dinâmica sobre as vertentes situadas no Maciço Central, sendo a maior incidência dos eventos pluviométricos, ao qual tal processo se alia, verificada no verão, freqüentemente em janeiro.Este trabalho analisa aquela paisagem segundo os seus aspectos de inclinação, hipsometria, processos morfodinâmicos, tipologias de solos, litologia, drenagens, lineamentos estruturais, uso e ocupação antrópica, cujos padrões se agrupam no estabelecimento das relações ambientais específicas. Essas relações são abordadas por meio da perspectiva integradora das características do relevo, avaliadas após a definição do padrão genético da estrutura geomorfológica e da distribuição espacial das características morfodinâmicas frente ao quadro atual da organização ambiental.

\section{eses es es}

"Processos hidrogeomorfológicos e o uso da terra em ambiente subtropical-Guarapuava-PR

\section{Edivaldo Lopes Thomaz}

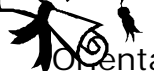

$$
\text { tador: Prof. Dr. Jurandyr L. S. Ross }
$$

O presente estudo trata do tema: Processos hidrogeomorfológicos e o uso da terra em ambiente subtropical - Guarapuava - PR. Os processos hidrológicos e geomorfológicos são influenciados pela forma do relevo e pelo uso da terra. Buscou-se, compreender a relação entre forma, material e processo permeada pelo uso da terra. Avaliou-se a dinâmica da paisagem atual em área rural, no sentido de analisar mudanças físico-hídricas no solo, interceptação da chuva, escoamento superficial e produção de sedimento em diferentes unidades de terras. Os 
experimentos foram conduzidos priorizando solo raso, pedregoso e recobrindo vertente declivosa. A análise de sistema foi o embasamento teórico, sendo que a bacia de drenagem foi considerada unidade fundamental para o desenvolvimento dos ensaios em geomorfologia experimental. A metodologia empregada seguiu a proposição empírico-cartográfica e experimental. Aliou-se o mapeamento da paisagem, a observação direta dos processos e mensurações. Os experimentos em campo foram divididos em três níveis (etapas): a) Processos hidrogeomorfológicos e uso da terra (primeiro nível); b) Processos hidrogeomorfológicos em vertente (segundo nível); c) Processos hidrogeomorfológicos em segmento retilíneo (terceiro nível). Com esse procedimento, procurouse aprofundar a análise, das formas, dos materiais e dos processos em cada um dos níveis, no que se refere, à perspectiva horizontal e vertical da paisagem estudada. O monitoramento foi conduzido entre novembro de 2001 a abril de 2004. Verificouse, que as práticas agrícolas nas diferentes unidades de relevo, impuseram uma resposta complexa na

\section{A contra-reforma agrária do banco mundial} e os camponeses no Ceará-Brasil

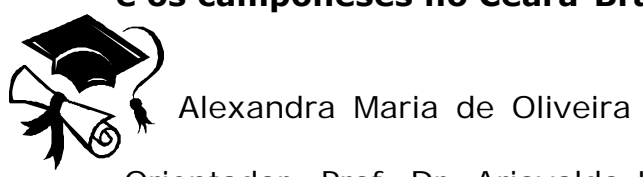

Orientador: Prof. Dr. Ariovaldo Umbelino de Oliveira

Esta tese analisa a política de crédito fundiário no Ceará, posta em prática pelos governos estadual e federal em parceria com o Banco Mundial a partir de 1996. A forma pela qual o Estado foi levado a dar início e desenvolver a "reforma agrária de mercado" no Ceará, recoloca problemas importantes: a questão da reforma agrária e o acesso à terra pelos sem terra, o problema da estrutura fundiária no Ceará, no Nordeste, e em outras regiões. Simultaneamente, repõe o problema da "adaptação" de moradores de condição, parceiros, rendeiros e migrantes temporários ao mercado capitalista.A reflexão sobre a contrareforma agrária do Banco Mundial e os dinâmica hidrogeomorfológica das vertentes. Por decorrência, ocorreu ampla variabilidade têmporoespacial, no uso da terra, nos processos hidrogeomorfológicos e na degradação dos solos nos três níveis avaliados. Além disto, as formas de relevo influenciaram na variabilidade têmporoespacial acerca dos limiares dos processos hidrogeomorfológicos. O segmento de vertente retilínea foi o mais sensível às mudanças no uso da terra. As práticas agrícolas em agricultura de subsistência leva a um comportamento periódico, entre 3 a 5 anos, em que ocorre forte incremento na produção de sedimento com posterior diminuição. Este padrão de produção de sedimento segue a dinâmica do sistema de rotação de terra com as fases: roçar-queimar-cultivar-abandonar-regenerar. O procedimento, empírico-cartográfico e experimental, empregado mostrou-se satisfatório em relação à condução da pesquisa e no alcance dos resultados propostos. Esta abordagem permitiu enfoques diferentes, porém complementares em relação ao estudo de processos em geomorfologia.

$$
\text { coseres }
$$

camponeses passa pela discussão acerca do desenvolvimento territorial contraditório, desigual e combinado, desenvolvido no interior da Geografia agrária. A pesquisa foi desenvolvida a partir de um estudo transversal realizado em oito assentamentos criados a partir dos projetos São José e Cédula da Terra, partes constitutivas da denominada "reforma agrária de mercado" no Ceará. A implementação da "reforma agrária de mercado" no Ceará, tem significado a reativação do mercado de terras contribuindo para a ampliação das relações, especificamente capitalistas no campo como a apropriação da renda capitalizada da terra por proprietários de terras rentistas. Os assentamentos como frações do território conquistadas se constituíram com base na propriedade familiar que é uma forma de propriedade diferente da propriedade privada capitalista. A apropriação familiar e o desenvolvimento de formas de trabalho como o individual (familiar), a prática de ajuda mútua, o uso comum da terra e o trabalho coletivo revelam a ocorrência de formas alternativas para a propriedade privada imposta pelo Estado. Existe, 


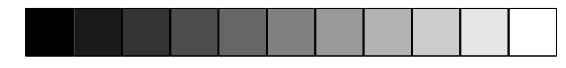

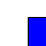

Teses de Doutorado e Dissertações de Mestrado Defendidas

(Novembro de 2005 a Abril de 2006), pp. 245 - 270

portanto, um sério conflito entre o regime de propriedade privada implementado sob a lógica de mercado do Estado e a concepção de propriedade familiar reproduzida pelos camponeses e legitimada com o apoio dos movimentos sociais e das entidades camponesas em luta pela reforma agrária no país

$$
\text { cescestes }
$$

Desenvolvimento regional e produção espacial turística: Punta del Diablo-Uruguai

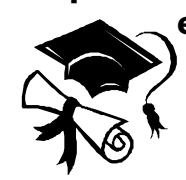
e Serra da Capivara-Brasil

Álvaro Castroman Polero

Orientador: Prof. Dr. Eduardo Yázigi

A produção espacial do turismo é uma dinâmica que modifica processos, formas e conteúdos de uma realidade maior, a regional. Esta investigação tem como objetivo analisar essa produção dentro da complexidade da região, sob a perspectiva geográfica dos multicritérios. Essa perspectiva está orientada, desde o primeiro momento, a identificar problemáticas, dinâmicas e tipologias da configuração regional, além de investigar as oportunidades e as ameaças da produção espacial turística relacionadas à multifuncionalidade regional. O estudo possui etapas exploratórias, descritivas e explicativas; sua metodologia é geográfica na qual utilizamos conceitos da UCM (2004), da OMT (1998) e de nossa proposta teórico-metodológica (MATE). As regiões em estudo são a Serra da CapivaraBrasil e a Punta del Diablo-Uruguai.Como resultados, constatamos várias inter-relações dinâmicas e complexas do turismo com os diferentes subsistemas regionais, que algumas vezes têm sido benéficas e em outras nocivas para o desenvolvimento da região. Devidamente planejada e gerida, a produção espacial do turismo pode revitalizar e equilibrar a multifuncionalidade regional.

\section{Sistema de informação geográfica, monitoramento da qualidade da água e a atividade turística : reflexões sobre o município de Caconde, estado de São Paulo

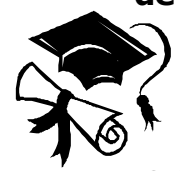 \\ Antonio Aparecido de Souza}

Orientador: Prof. Dr. Reinaldo Paul Pérez Machado

O trabalho que ora se apresenta é decorrente das reflexões encadeadas durante o transcorrer do curso de pós-graduação em Geografia Humana da Universidade de São Paulo. Uma das preocupações prementes dentro da organização da sociedade do início do século XXI passou a ser a preocupação com o ambiente e com os impactos que este pode estar submetido a partir de sua exploração. A investigação que se desenvolveu e que aqui esta sendo resumida buscou uma maior aproximação com relação às técnicas de monitoramento da qualidade do ambiente e de como este se relaciona com a atividade turística, especificamente no município de Caconde. Para a montagem deste quadro de referência foi utilizada a perspectiva sistêmica de pesquisa para instrumentalizar a obtenção de resultados sobre como se dá a passagem dos fluxos de matéria e energia pelo território do município, particularmente da água. Para tal análise foram utilizados o kit de análise de parâmetros físicos e químicos da água, chamado "ecokit" e também o kit "tecnobac" utilizado para quantificar os parâmetros microbiológicos da mesma. A cobertura vegetal nativa foi monitorada tendo como limite pretérito máximo o ano de 1990 até abril de 2005 com o uso de imagens orbitais originadas pelos sensores à bordo dos 
sistemas Landsat 5 e 7 e dos sistemas CBERS 1 e 2. Também se integraram a este conjunto de dados os registros fotográficos feitos em solo no município. Após a obtenção de todos estes dados ainda ocorreu a aplicação de questionários semiestruturados para que fosse possível obter uma impressão sobre como os vários integrantes dos processos que redundam em atividades econômicas, como por exemplo, o turismo integram em seu discurso as questões ambientais e aquelas voltadas ao sentimento de pertencimento. Os resultados foram apresentados em forma de gráficos, mapas, cartogramas e imagens orbitais e por explanação textual ao final da apresentação dos dados.Feita esta análise é que se buscou encadear idéias que pudessem oferecer aos interessados pelo assunto, no município e foram dele, uma contribuição à mais para se repensar o espaço geográfico.

\section{Letes}

\section{Do "entesouramento" à acumulação urbana: a produção do espaço de Fortaleza no século}

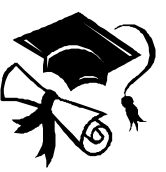

Ana Cristina Mota Silva

Orientador: Prof. Dra. Amélia Luíza Damiani

A pesquisa sobre a cidade de Fortaleza no dezenove busca compreender, a partir de uma análise de documentos históricos, atas da câmara, inventários, relatórios da província e correspondências, etc. quais foram os elementos constitutivos que possibilitaram a produção espacial desta cidade. Para isto, as determinações da metamorfose do "entesouramento" à realização do processo de acumulação, como momentos fundantes da formação do patrimônio dinheiro e de um projeto mercantil, coloca como condição necessária a compreensão de que tais momentos exigem como seus a produção espacial da vila como condição primeira, embora determinada pela forma - valor que produz tais momentos como sua efetivação. Isto significa dizer que as exigências deste momento e processo se constituem na formação de uma riqueza que torna o urbano investimento seletivo e isto envolve, de início, a transferência de uma riqueza posta no gado e no algodão, ou seja, a transferência de uma renda do campo para a produção espacial desta cidade. Contudo, a realização do espaço urbano pela forma urbana redefine não somente as relações sociais no campo, mas revela temporalidades e espacialidades contraditórias, no instante em que a reunião sob a forma da simultaneidade de processos de aforamentos, arrendamentos, dízimo, décima, aluguéis, posses, compra, venda, cercamentos, hipoteca, expropriações, rendimentos, dentre outros, contribuem para pensar que tanto a produção espacial da cidade, como também a formação da riqueza como momentos de síntese, colocam, como condição, estas descontinuidades, de modo que a imobilização se constituiu como um momento, seja ela dos bens inventariados, mas ainda, singularmente, dos imóveis imobiliários, como forma de tornar esta metamorfose e produção espacial - a cidade como negócio - um momento possível da acumulação monetária 
Construção dos conceitos científicos e escolares: caminhos para a organização da educação geográfica

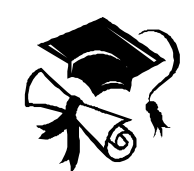

Marcos Antônio Campos Couto

Orientador: Prof. Dra. Sônia Maria Vanzella Castelar

Esta tese constitui uma análise do papel da construção dos conceitos científicos na organização do ensino de geografia. Com base nas referências teóricas da psicologia histórico-cultural de L. S. Vygotsky e V. V. Davýdov e na concepção dialética e materialista de conhecimento - que lhe é inerente - analisamos o papel dos conceitos em suas dimensões psicológica e lógica. O aprendizado escolar dos conceitos científicos influencia o desenvolvimento intelectual, interferindo na forma, no método e no conteúdo do raciocínio das crianças. Um dos elementos psicológicos fundamentais inerentes ao processo de formação dos conceitos científicos na criança é o estabelecimento das suas interdependências, que impõe a necessidade de identificar os conceitos básicos da geografia e verificar suas relações, dependências e reciprocidades.
Abstrato e concreto, geral e particular (e singular), essência e fenômeno, análise e síntese, visível e invisível etc, constituem categorias gerais correspondentes à estrutura lógica do pensamento, que permitem refletir a lógica das coisas, destacando suas propriedades fundamentais. Os conceitos geográficos que permitem refletir o objeto de estudo da geografia e seus dados experimentais, devem expressar o conteúdo e o movimento destas categorias da lógica. Conceito científico é uma generalização da realidade que permite ao pensamento fazer os movimentos do geral para o particular e do particular para o geral, e, com isso, reproduzir pensamento nexos, relações e dependências complexas entre os fenômenos. A junção dos aspectos lógico e psicológico, combinado com o conteúdo epistemológico dos conceitos científicos, permite refletir sobre novos princípios de organização do ensino de geografia. A construção dos conceitos científicos é fundamental no processo de ensinoaprendizagem dos conteúdos geográficos, na medida em que interfere no desenvolvimento intelectual dos alunos e constrói o pensamento teórico-científico, indispensável à compreensão dos fenômenos através da reprodução dos seus nexos, relações e dependências complexas.
O setor agropecuário no contexto da sustentabilidade: a região oeste do Estado de São Paulo

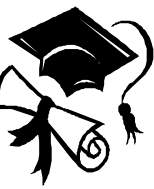

Mário Pires de Almeida Olivetti

Orientador: Prof. Dr. Luiz Augusto de Queiroz Ablas
Este estudo se pauta no questionamento do atual modelo de desenvolvimento e na busca do chamado desenvolvimento sustentável que, segundo a Organização para a Cooperação Econômica e Desenvolvimento, (OECD), é definido como o uso dos recursos naturais e humanos de forma a garantir as necessidades atuais sem o comprometimento da capacidade de produção para as gerações futuras. Essa nova premissa reivindica e aspira por 
melhorias na qualidade de vida para o conjunto da população; sob a ótica da análise regional busca compreender como se insere o setor agropecuário da região Oeste do Estado de São Paulo nesse paradigma. É com esse foco que essa tese de doutorado é realizada tendo como objetivos específicos: procurar compreender as condições sociais, econômicas e ambientais, identificando e indicando as localidades com sistemas produtivos com maior ou menor sustentabilidade. Busca-se, assim, também avaliar a capacidade dos indicadores aplicados de captarem os diferentes níveis de sustentabilidade, em especial a sócio-espacial, permitindo que se caminhe em direção de alternativas consistentes, na tentativa de solucionar alguns dos problemas que permeiam a sociedade e os recursos naturais. Para estabelecer as configurações dos municípios que compõem a região Oeste do Estado de São Paulo utiliza-se técnica de análise multivariada (fatorial e agrupamento). Os 150 municípios pertencentes à região Oeste foram os elementos observados e as 33 variáveis selecionadas para caracterizar esses elementos, foram: disponibilidade de mão-de-obra, renda, educação e saúde; distribuição territorial: da concentração da posse da terra, da população e das explorações agropecuárias. Considerou-se ainda a pressão econômica e demográfica sobre o meio ambiente, e da capacidade produtiva decorrente de fatores, como a adoção das práticas agrícolas, $C \& \mathrm{~T}$, acesso à assistência técnica e mão-de-obra, cujos efeitos podem ser refletidos no índice da eficiência técnica da produção agrícola. Os resultados obtidos, que visam avaliar a sustentabilidade, retrataram e permitiram verificar que nenhum dos municípios da região Oeste paulista possui características desejáveis que contemplem o paradigma da sustentabilidade. Aliás, alguns apresentaram desempenho bem sofrível de acordo com determinados índices utilizados.Os indicadores sócio-econômicos atestaram a importância das variáveis selecionadas e do método aplicado para estudos dessa natureza. Foi possível desenhar um mosaico da heterogeneidade espacial existente nessa região, corroborando empiricamente o que diversos pesquisadores assinalam como fatores básicos na busca do desenvolvimento sustentável, notadamente do setor agropecuário.

\section{A luminosidade do lugar: circunscrições intersticiais do uso de espaço em Belo Horizonte: apropriação e territorialidade no bairro de Santa Tereza}

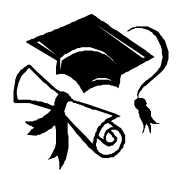

Ulysses da Cunha Baggio

Orientador: Prof. Dra. Amélia Luisa Damiani

Este trabalho se propõe a uma análise e a uma avaliação de práticas de uso do espaço na cidade de Belo Horizonte, a partir das quais se discutem as suas possibilidades e limites na contemporaneidade capitalista. Este percurso remete o pensamento às idéias de apropriação e de territorialidade, abordadas a partir de alguns recortes sócioespaciais desta cidade, quais sejam, o extinto Bar do Ponto, o Mercado Central de Belo Horizonte, o bairro Belvedere lll e, principalmente, o bairro de Santa Tereza, localizado na região leste da capital, e que mereceu um capítulo à parte (cap. 3) neste trabalho. À exceção do Belvedere III, a análise acerca da apropriação e da 

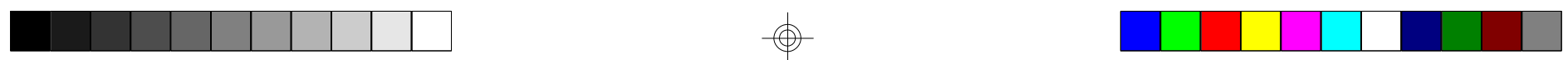

Teses de Doutorado e Dissertações de Mestrado Defendidas

(Novembro de 2005 a Abril de 2006), pp. 245 - 270

constituição da territorialidade se desdobra sobre práticas e modos territoriais de vivência atinentes a estes lugares, principalmente o Mercado Central e, em especial, e com maior destaque, o bairro de Santa Tereza. Sustenta-se que tais manifestações sócio-espaciais circunscrevem-se nos interstícios da cidade de Belo Horizonte como permanências e resistências insurgentes, ao longo do percurso de sua formação. Compreende-se aqui que estas práticas de insurgência sócioespacial são engendradas no universo mais amplo da produção ampliada e contraditória da cidade, irrompendo-se, mais propriamente, no âmbito duro de situaçõeslimite à reprodução social, estabelecidos pela proeminência espaço-temporal do valor de troca e do mundo da mercadoria. Assim, a análise se desenvolve na perspectiva do conflito permanente entre valor de troca e valor de uso, ou ainda, entre a propriedade e a apropriação, universo em que se produzem práticas sócio-espaciais reativas de matizes diversos como, por exemplo, movimentos de moradores e outras formas de luta urbanas. Desse modo, a perspectiva que se abre sobre a cidade, e a metrópole, é a de uma geografia em movimento, que valoriza o lugar e suas possibilidades à vida humana.

Les

\author{
A territorialidade dos conglomerados \\ financeiros no Brasil \\ Márcio Fernando Gomes \\ Orientador: Prof. Dra. Sandra Lencioni
}

A presente pesquisa trata do território-rede dos conglomerados financeiros no Brasil no final do século $X X$ e início do século $X X I$.Esta pesquisa versa sobre o caso de cinco conglomerados financeiros formados a partir dos bancos comerciais: Brasil, Nacional, Bamerindus, Bradesco e Itaú. Por um lado, argumenta sobre os conglomerados financeiros atuando em empresas do setor de serviços financeiros. Por outro lado, argumenta sobre as novas formas jurídicas de concentração empresarial que possibilitaram os bancos comerciais ampliarem seus investimentos em empresas de diversos setores e diferentes tipos e negócios. Apresenta as expressões materiais e imateriais destes conglomerados financeiros por meio da análise da difusão informacional que responde a reestruturação informacional e do esquema relacional de poder que responde a reestruturação organizacional. Esta tese de Doutorado ao descrever a territorialidade do territóriorede nacional de alcance internacional dos conglomerados financeiros no Brasil procura contribuir para compreensão da sua gênese e da sua territorialização pelo contexto da transgressão de reprodução do capital, o qual o transforma cada vez mais em capital especulativo e, pelo contexto da nova base territorial de reprodução do capital, a qual - faz transitar cada vez mais por um território-rede global. Esta tese argumenta que estes conglomerados financeiros seja condição, meio e produto de uma nova relação espaço e tempo, originada na transgressão de reprodução do capital e na nova base territorial de reprodução do capital que transforma o capital financeiro da sua face fictícia à especulativa na perpesctiva da formação da renda capitalizada em dinheiro. 


\section{Água e metrópole: limites e expectativas do tempo financeiros no Brasil}

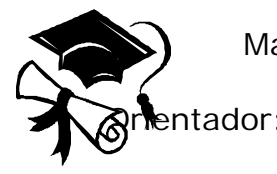

Maurício Waldman

Prof. Dr. Ariovaldo Umbelino de Oliveira

Água e Metrópole, Limites e Expectativas do Tempo, é uma tese que analisa a dificuldade crescente das grandes metrópoles serem atendidas nas suas demandas por água. Esclarecendo a respeito da questão central deste trabalho, a hipótese básica é de que esta demanda não poderá ser satisfeita a não ser que se implantem mudanças radicais nas mais diversas escalas da vida humana. Neste sentido, este texto dedica grande atenção para a modalidade linear e progressiva da temporalidade que caracteriza a modernidade. Foi com base neste ordenamento do tempo que - mercado conquistou sua hegemonia na sociedade, entendimento que também permite compreender a forma como a relação com o meio ambiente passou a ser construída no pensamento ocidental. Com efeito, o debate relacionando água e metrópole não pode se isentar da articulação que estas duas temáticas sustentam com a questão socioambiental. As cidades correspondem ao principal ambiente de vida da humanidade nos dias atuais, assim como o espaço por excelência a partir do qual emana a ordenação temporal que caracteriza a modernidade. Ademais, é também no ambiente urbano, máxima expressão da hegemonia de um tempo subsidiado pelo mercado, que a exclusão social predomina, configurando um quadro marcado por todo tipo de contradições e dentre estas, a que tem se materializado pela sede. Nesta perspectiva, paralelamente ao levantamento das diferentes interfaces suscitadas pela questão dos recursos hídricos, enfoca a região metropolitana de São Paulo e do grande $A B C$, casos entendidos como emblemáticos para a compreensão desta problemática.Por fim, esta tese enseja a discussão de diversas contradições que perpassam pela sociedade contemporânea, tais como os limites institucionais frente à questão ambiental, a dimensão da expansão urbana e sua associação com a questão social e da utilização dos recursos hídricos, todas de fundamental importância para que se possa pensar num novo tempo, móvel para a construção de um novo espaço de vida, socialmente justo e ecologicamente responsável.
Globalização, turismo de fronteira, identidade e planejamento da região internacional de Corumbá/MS

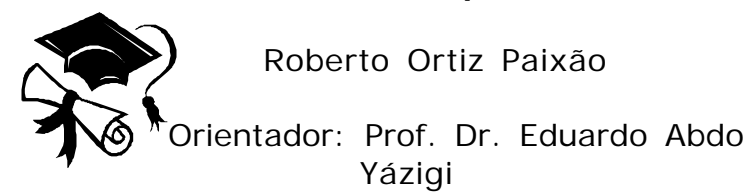

Este trabalho é uma contribuição teóricometodológica aos estudos sobre o planejamento regional do turismo em áreas de fronteira, tendo como foco central da pesquisa a Região de Corumbá/MS, na fronteira do Brasil com a Bolívia. Esta região foi apreendida como um subespaço do espaço global, levando em conta seus processos histórico e econômico, bem como a natureza de sua fisiografia. A abordagem do objeto de estudo no campo teórico-metodológico partiu de uma conjuntura global para o plano regional, em seis capítulos. No primeiro capítulo delineia-se um panorama do período posterior à Segunda Guerra Mundial e os seus reflexos sobre a globalização, as fronteiras e a atividade turística. No segundo capítulo, a discussão passa a ser centrada na dinâmica das fronteiras e suas implicações para o turismo, com uma proposta de categorização de tipos de turismo nas áreas de fronteiras. No terceiro capítulo, são discutidas algumas experiências de planejamento regional em áreas de fronteiras sob o enfoque do turismo. O quarto e quinto capítulos voltam-se para a Região Internacional de Corumbá em seus mais 

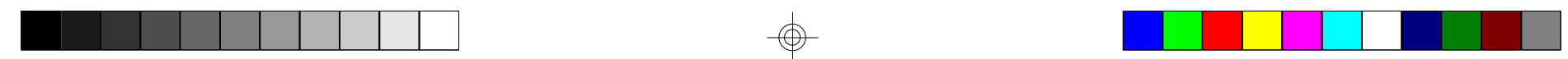

Teses de Doutorado e Dissertações de Mestrado Defendidas

(Novembro de 2005 a Abril de 2006), pp. 245 - 270

variados aspectos, como a localização, a formação natural e os usos sociais, com ênfase ao turismo. O quinto capítulo trata do desenvolvimento do turismo na região em suas diferentes modalidades com destaque para 0 turismo de pesca. O sexto capítulo indica as perspectivas para a consolidação formal de uma região turístico-fronteiriça integrada, sob a tutela do Estado, o que se entende ser o caminho mais plausível para o desenvolvimento regional desta fronteira. Isso valida a hipótese de que os problemas existentes no setor turístico de Corumbá passam pela construção de uma Região Internacional de Planejamento envolvendo Ladário, Puerto Quijarro e Puerto Suarez. Finalmente, são apresentadas algumas diretrizes para essa construção.

\section{Lesers ex}

Zoneamento ambiental de um setor do Parque Estadual da Cantareira e entorno seccionado pela Rodovia Fernão Dias (BR381)

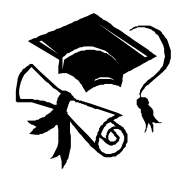

Dimas Antônio da Silva

Orientador: Prof. Dr. Felisberto

Cavalheiro (in memoriam)

Este estudo apresenta o zoneamento ambiental de um setor do Parque Estadual da Cantareira e entorno seccionado pela Rodovia Fernão Dias (BR 381). Foi realizado com base em uma abordagem sistêmica, considerando-se a integração das informações referentes ao meio físico-biótico, uso da terra e aspectos legais, obtidas por meio de levantamentos bibliográfico e cartográfico, interpretação de produtos de sensores remotos e trabalhos de campo. A área de estudo apresenta três setores bem distintos: na face norte observa-se uma ocupação esparsa entremeada por remanescentes florestais expressivos; na face sul ocorre uma maior diversidade de classes de uso da terra, caracterizada por áreas urbanas consolidadas e em processo de urbanização, atividades hortifrutigranjeiras, pedreiras, aterros sanitários, reflorestamentos e cobertura florestal mais fragmentada; separando estas duas faces, destaca-se o Parque Estadual da Cantareira coberto, em quase sua totalidade, pela floresta nativa. Verificou-se que os instrumentos de planejamento urbano e a legislação ambiental incidentes na área não foram eficientes no controle da expansão da mancha urbana em direção ao Parque, ocasionando a ocupação de setores frágeis do ponto de vista geomorfológico e a degradação ambiental. A proposta de zoneamento ambiental e as recomendações apresentadas procuram subsidiar a revisão do plano de manejo do Parque, colaborar para definição de sua zona de amortecimento, de modo a reverter a tendência crescente de isolamento desta unidade de conservação no contexto urbano, e contribuir para sua preservação, contribuindo para a melhoria da qualidade ambiental da Região Metropolitana de São Paulo. 


\section{Dissertações de Mestrado}

\begin{abstract}
Saneamento ambiental e urbanização: levantamento e análise da qualidade das águas na sub-bacia hidrográfica do Córrego da Água Branca, Ilhabela, São Paulo
\end{abstract}

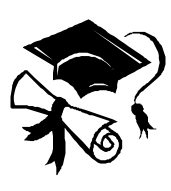

Carlos Eduardo Felgueiras

Orientador: Prof. Dra. Sueli Angelo Furlan
O presente trabalho tem como objetivo principal apresentar resultados de pesquisa acerca das necessidades de preservação de um dos mais importantes recursos naturais existentes, a água. A pesquisa teve como principais eixos de análise, o estudo das relações entre a expansão urbana, o saneamento ambiental e a qualidade da água no âmbito do planejamento ambiental, considerando às variações de uso da terra/ cobertura do solo na sub-bacia hidrográfica do Córrego da Água Branca/Tocas, Município de Ilhabela, São Paulo.
Avaliação dos processos erosivos, sedimentológicos e da qualidade de água da bacia hidrografica do Capivari (Apa Municipal Capivari-Monos-SP)

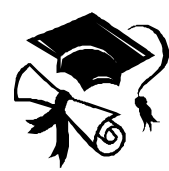

Isabel Utimura

Orientador: Prof. Dr. Ailton Luchiari

O território delimitado como Área Proteção Ambiental - APA Municipal do Capivari-Monos abriga um dos poucos remanescentes da Mata Atlântica e dois rios efetivamente limpos, com elevado potencial para manancial, na região metropolitana de São Paulo. Neste contexto, insere-se a Bacia Hidrográfica do Rio Capivari, uma área de elevado grau de preservação ambiental, bastante representativa para os objetivos desta pesquisa: testar e validar a metodologia proposta para o diagnóstico da fragilidade natural do meio físico aos processos erosivos e sedimentológicos, em bacias hidrográficas. Investigaram-se as relações existentes entre o grau de concentração de sedimentos nas águas de alguns canais de drenagem, em função das características físicas e de uso do solo da bacia. Durante um ano hidrológico, foram realizadas amostragem das águas de sete canais de drenagem e determinados, analiticamente, alguns parâmetros físicos da qualidade da água. As variáveis: solo, relevo, declividade do terreno, cobertura vegetal, uso e ocupação da terra foram analisadas por meio de geoprocessamento, o que possibilitou a confecção dos produtos cartográficos finais deste estudo, apresentado nos mapas-síntese de fragilidade potencial e ambiental da bacia. Os procedimentos dos métodos desenvolvidos elucidaram algumas relações sistêmicas entre os elementos componentes da paisagem e as conseqüências dos processos superficiais nos recursos hídricos da área. Esta pesquisa fornece subsídios para servir de modelo de abordagem metodológica, visando auxiliar futuros programas de manejo dos solos e recursos hídricos, dentro de novo conceito de manejo ambiental, que vêm se desenvolvendo em microbacias, além de difundir nova concepção da importância da integração da informação neste processo. 


\section{Expansão urbana e evolução geomorfológica em remansos de reservatórios : análise comparativa de duas bacias hidrográficas em Guarapiranga, São Paulo

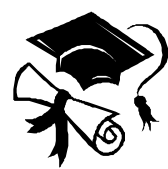 \\ Juliana de Paula Silva}

Orientador: Prof. Dra. Cleide Rodrigues

Os problemas ambientais gerados pelo crescimento urbano acelerado nos últimos 50 anos tem trazido graves conseqüências para o conjunto da população residente nos grandes centros urbanos. Por este motivo muitos cientistas, especialmente na área de ciências da Terra, têm buscado o desenvolvimento de novas técnicas, metodologias e parâmetros para dimensionar, reconhecer e reverter e/ou atenuar os efeitos destes processos de degradação. $O$ objetivo central deste trabalho é reconhecer e dimensionar, por meio de leituras geomorfológicas, a expansão urbana como uma modalidade de intervenção antrópica capaz de modificar processos geomorfológicos e imprimir uma nova morfodinâmica em sistemas físicos afetados. Através deste objetivo central buscou-se aplicar e testar metodologias e parâmetros propostos pela geomorfologia antrópica no contexto de um país em desenvolvimento localizado no domínio climático tropical úmido.Segundo RODRIGUES (1997a) por meio da utilização das ferramentas da geomorfologia, é possível desenvolver propostas metodológicas específicas que inserem a ação antrópica como agente modificador de sistemas da superfície terrestre, tal como em TOY \& HADLEY (1987); DOUGLAS (1983); TRICART (1977); TRICART \& KILLIAN (1979); NIR (1983); DOUGLAS (1983); HART (1986); VERSTTAPEN (1983); GUPTA (1999a) e COLTRINARI (2001). Nesta pesquisa, uma parte deste referencial metodológico foi aplicado, como a antropogeomorfologia NIR (1983), a cartografia geomorfológica RODRIGUES (1997a);
LIMA (1990) e os Geoindicadores COLTRINARI (2001); GUPTA, (1999b) para avaliar e comparar quantitativamente e qualitativamente as mudanças geomorfológicas (formas, processos e materiais) observadas na interface flúviolacustre (remansos) de duas Bacias Hidrográficas, uma com quase toda a área em estágio avançado de urbanização e outra com a maior parte de sua área sem perturbação antrópica. A comparação entre os resultados encontrados em cada Bacia Hidrográfica possibilitou acompanhar as mudanças promovidas pela urbanização durante o período estudado.As áreas escolhidas como objeto de estudo são duas sub-bacias hidrográficas inseridas no manancial da Represa Guarapiranga, localizadas na Zona Sul do município de São Paulo. Essa seleção deu-se principalmente em função das características morfológicas e morfométricas semelhantes de sub-bacias hidrográficas e em função da dinâmica diferenciada do processo de urbanização em cada uma delas. Por outro lado, a importância da represa no contexto metropolitano proporcionou uma geração contínua de dados ao longo de todo o séc. $X X$ que ainda se encontram disponíveis para consulta, tais como: fotografias aéreas, mapas, sondagens, dados de operação, entre outros.As mudanças espaciais GREGORY (1992) ocorridas ao longo da história da represa e entorno imediato foram analisadas por meio da produção cartográfica em escala de detalhe $(1: 5.000)$ para os anos de 1932, 1962, 1972, 1986, 1994 e 2000 nos remansos selecionados para a avaliação dos processos morfodinâmicos gerados pela urbanização após a construção da barragem do reservatório em 1906.Os resultados encontrados foram de caráter quantitativo: área colmatada nos remansos selecionados e evolução do uso da terra nas bacias hidrográficas, qualitativos: mudanças espaciais na morfologia e nos canais fluviais promovidos pela urbanização, e analíticos, através do emprego e análise de novas metodologias que vêm enriquecer as possibilidades de aplicação da geografia física. 


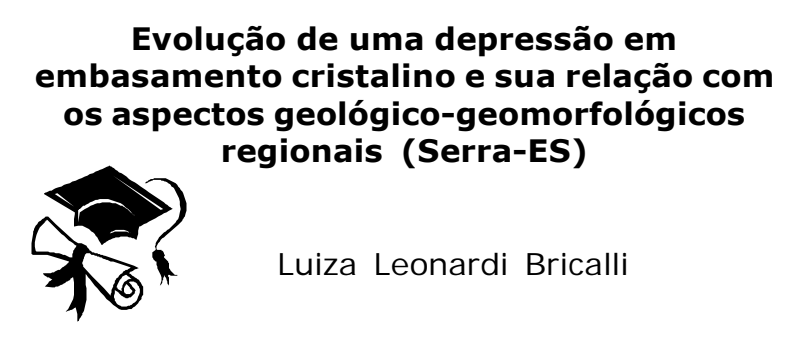

Orientador: Prof. Dr. José Pereira de Queiroz Neto

Este estudo refere-se a um trabalho de Geografia Física, de cientificidade bipartite geomorfologia e pedologia - com ênfase no estudo dos materiais, representado pelos solos, a partir da aplicação do procedimento da Análise Estrutural da Cobertura Pedológica.Trata-se de um estudo de uma feição geomorfológica, uma depressão em topo e vertente de uma colina ao redor de um maciço granítico denominado "Mestre Álvaro", localizado no município de Serra (ES), depressão esta denominada de depressão "L". Foi iniciado com o curso Análise Estrutural da Cobertura Pedológica (outubro de 2002) realizado na depressão. Desse trabalho inicial surgiu a possibilidade de dar continuidade à pesquisa com o objetivo de caracterizar a organização da cobertura pedológica da depressão e vertentes adjacentes, a partir da abordagem da Análise Estrutural da Cobertura Pedológica e de levantar hipóteses sobre sua gênese. O trabalho foi realizado em três fases distintas, mas interligadas: campo, gabinete e laboratório e para atingir os objetivos propostos preocupou-se em contextualizar regionalmente esta depressão quanto aos aspectos geomorfológicos, geológicos, climáticos, pedológicos e de vegetação a partir do estudo em diferentes escalas (regionais e locais) no entorno da área da depressão (escalas 1:1.000.000, 1:38.000.000, $1: 50.000,1: 25.000)$; na colina da depressão (escala 1:9.000) e; na depressão propriamente dita (escala 1:1), partindo da premissa de entender o geral para entender o específico. Ao final, chegamos às seguintes conclusões: 1) a evolução da depressão está relacionada a variáveis físicas geográficas diferenciadas e, no entanto, correlacionadas; 2) há uma forte influência da tectônica (lineamentos estruturais) no relevo da área; 3) a depressão "L" é a única localizada em relevo cristalino, existindo outras próximas a esta, mas com características litológicas, geomorfológicas e morfológicas diferenciadas; 4) parece haver dois processos atuantes que se destacam na depressão: físicos (erosão superficial) e químicos (erosão subsuperficial: erosão geoquímica); 5) os trabalhos de campo juntamente com as análises de laboratório permitiram classificar o solo da depressão em Gleyssolo Háplico segundo a Classificação Brasileira de Solos; 6) verificamos a grande importância em estudar os materiais (solo e rocha) para estudos de relevo, pois este é o que se enxergamos, e para entendê-lo devemos incorporar com o conhecimento do que existe abaixo da superfície; 7) Houve uma grande relevância em compatibilizar as escalas macro (mapeamentos, perfis topográficos) com as escalas micro (toposequências, trincheira, análises de amostras em laboratório) pois permitiu espacializar e globalizar as diversas variáveis físicas geográficas existentes na paisagem a partir das mais diversas correlações feitas. 


\section{Geografia física : balanço da sua produção em eventos científicos no Brasil}

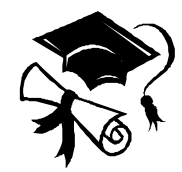

Marcos Barros de Souza

Orientador: Prof. Dra. Sueli Angelo Furlan

Discutir as tendências teóricas e conceituais da Geografia física é fundamental para que se possa visualizar trajetórias, abordagens, influências e debates que ocorreram na Geografia nos últimos 50 anos. Foi realizado um balanço dos trabalhos produzidos e publicados nos Anais e/ou Caderno de Resumos e Contribuições Científicas de eventos científicos, ocorridos no período de 1954 a 2004, tais como: Congresso Brasileiro de Geógrafos, Encontro Nacional de Geógrafos, Encontro Nacional de Estudos Sobre o Meio Ambiente, Simpósio Brasileiro de Geografia Física Aplicada, Simpósio Brasileiro de Climatologia Geográfica e Simpósio Nacional de Geomorfologia. Esta pesquisa teve como objetivos: realizar levantamento bibliográfico e destacar alguns aspectos do percurso histórico da Geografia no mundo e no Brasil, destacando a Geografia Física; efetuar balanço de como vem sendo

\section{Estudo da dinâmica de urbanização na bacia do córrego bananal município de São Paulo, através da utilização de técnicas de sensoriamento remoto e geoprocessamento

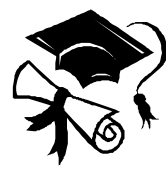 \\ Mônica Pavão \\ Orientador: Prof. Dr. Ailton Luchiari}

O objetivo deste trabalho é estudar a dinâmica de urbanização na Bacia do Córrego Bananal, Município de São Paulo, Brasil. A metodologia do trabalho baseou-se na utilização de técnicas de sensoriamento remoto e geoprocessamento para realizar estudos de fragilidade ambiental, identificar áreas homogêneas quanto ao padrão de habitação bem como realizar estudos sócio-econômicos que abordada a Geografia Física, em eventos científicos, utilizando-se como fonte de informações os Anais e/ou Cadernos de Resumos e Contribuições Científicas de eventos científicos realizados ao longo do período de 1954 a 2004; refletir sobre os direcionamentos da pesquisa em Geografia Física, contribuindo com uma visão crítica dos trabalhos analisados; identificar as tendências teóricometodológicas e temáticas dos trabalhos publicados nos Anais e/ou Caderno de Resumos e Contribuições Científicas de eventos científicos; discutir e levantar hipóteses dos motivos porque muitos geógrafos físicos participam de eventos ligados à outras áreas de conhecimento fora do âmbito da Geografia; discutir possíveis motivos para que alguns eventos ligados à área de Geografia Física pararam de ocorrer; refletir e analisar o atual momento da Geografia Física. Foi aplicado, também, um questionário junto aos membros de Comissões Organizadoras de eventos ligados à área de Geografia Física e entrevistas com geógrafos brasileiros que marcaram tendências teóricas da Geografia Física. A análise desses Anais e/ou Cadernos de Resumos e Contribuições Científicas permitiu a identificação dos diferentes tipos de trabalhos que foram publicados e divulgados e que estão diretamente relacionados com a área da Geografia Física, realizando, assim, uma classificação dos trabalhos baseada nas diversas subdivisões da Geografia Física.

tes ex es

caracterizam a população que habita a área. Os principais resultados demonstram que a utilização das técnicas de sensoriamento remoto e geoprocessamento são adequadas para estudos de monitoramento da expansão urbana. A utilização de imagens de satélite de alta resolução permitiu a identificação de Zonas Residenciais Homogêneas, quanto ao padrão construtivo, possibilitando sua caracterização do ponto de vista físico. Dados dos setores censitários do IBGE foram correlacionados às zonas residenciais homogêneas a fim de caracterizá-las do ponto de vista sócio-econômico. A utilização de técnicas de geoprocessamento foi importante para os estudos de fragilidade ambiental, pois permitiu correlações de levantamentos do meio físico e do meio sócio econômico, apontando áreas impróprias à ocupação humana. 


\section{Aquisição de conceitos cartográficos a partir do trabalho com o atlas escolar da cidade do Rio de Janeiro}

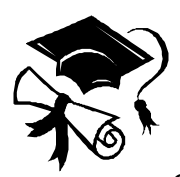

Tania Maria Ferreira Targino

Orientador: Prof. Dra. Maria Elena Ramos Simielli

O tema central dessa dissertação é demonstrar a contribuição do uso do Atlas Escolar da Cidade do Rio de Janeiro para a aquisição de conceitos cartográficos em séries iniciais do Ensino Fundamental.Percorremos um caminho no qual a proposta, desenvolvida por meio de questionários aplicados em turmas do primeiro segmento do Ensino Fundamental. Além disso, foram desenvolvidas atividades com os mapas do Atlas, visando possibilitar a construção de conceitos cartográficos considerados fundamentais para a leitura e compreensão de mapas pelos alunos: visão oblíqüa, visão vertical, escala, legenda, localização e orientação.Sobre a área do conhecimento relacionada aos aspectos psico-pedagógicos, Jean Piaget com as suas contribuições sobre o conhecimento cognitivo e seus estudos sobre epistemologia genética, sustentou o embasamento teórico para nossa pesquisa.Com esse trabalho destacamos a contribuição da cartografia escolar através dos atlas escolares, no processo ensino- aprendizagem da Geografia, recomendamos a representação cartográfica desde as séries iniciais e afirmamos que a alfabetização cartográfica contribui para um melhor do entendimento do espaço vivido.

$$
\text { extes }
$$

Sensoriamento remoto e geoprocessamento aplicados na análise da legislação ambiental no município de São Sebastião (SP)

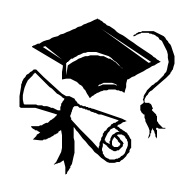

Ana Cristina Machado Rodríguez

Orientador: Prof. Dr. Reinaldo Paul Pérez Machado

A crescente ocupação urbana desordenada e inadequada vem acarretando sérios problemas ao meio ambiente nos últimos anos. Em algumas cidades, os assentamentos urbanos são localizados principalmente em regiões de encosta sem nenhum critério técnico ou projeto ambiental. Esse tipo de irresponsabilidade tanto da população como do próprio governo geram transgressões de leis ambientais e freqüentes acidentes nas épocas de chuvas torrenciais, resultando em grandes tragédias. Portanto, o estudo dos diversos tipos de uso do solo associado as suas características físicas é de extrema importância para o entendimento dos processos de preservação e conservação dos recursos naturais, e principalmente em relação à restrição ao uso das terras em áreas de risco de deslizamento, assegurando assim a qualidade de vida da população. Esta dissertação propõe a analise da legislação ambiental do município de São Sebastião no Estado de São Paulo através do uso do Sensoriamento Remoto e Geoprocessamento. A área de estudo tem uma extensão de 402,3 Km2 e está localizada no Litoral Norte de São Paulo. Este município apresenta uma pressão da expansão urbana que acarreta sérios problemas de deslizamentos nas épocas de chuva devido a assentamentos irregulares. A metodologia utilizada foi adaptada da proposta por CREPANI et al. (1996) e MORAES (1999). Neste trabalho foram utilizadas as imagens dos sensores TM, ETM+ e HRV dos satélites Landsat 5, 7 e Spot dos períodos de 1988 a 2002, assim como do Shuttle Radar Topographic Mission (SRTM) de 2000. A partir das imagens orbitais gerou-se um mapa temático de uso e cobertura do solo, e da imagem de radar as isolinhas e a carta de declividade da referida área de estudo. Estes produtos foram integrados e/ou cruzados juntamente com as variáveis ambientais de geologia, geomorfologia, geotecnia e solos 

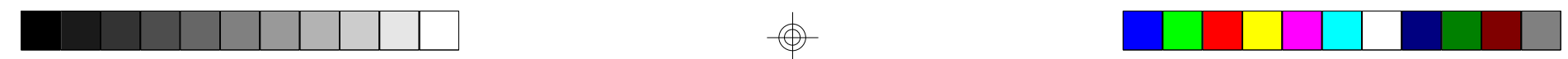

Teses de Doutorado e Dissertações de Mestrado Defendidas

(Novembro de 2005 a Abril de 2006), pp. 245 - 270

resultando no Mapa de Aptidão Física ao Assentamento Urbano. Este último foi integrado com o Mapa de Legislação Ambiental que contém as Áreas de Preservação Permanente (APP's) para gerar finalmente o Mapa de Incompatibilidade ao Uso. Todos os cruzamentos foram executados através da Linguagem Espacial para Geoprocessamento Algébrico (LEGAL) do software SPRING. Os resultados obtidos mostraram que existem poucas áreas compatíveis ao Uso, devido a Legislação Ambiental e também as características físicas da região. Existe ainda um avanço antrópico permanente em áreas de risco de deslizamentos e nas proximidades do limite do Parque Estadual da Serra do Mar (PESM), comprovando o desrespeito às leis ambientais. A identificação das áreas compatíveis para o assentamento urbano pode impedir a expansão do crescimento antrópico em áreas de risco, e também sobre a degradação ambiental em regiões de preservação no município de São Sebastião.

\section{ceses ex}

\section{Uso da terra nos arredores da represa \\ Billings e em Bertioga : o sensoriamento remoto na avaliação da expansão urbana em áreas de mata atlântica e de proteção de mananciais}

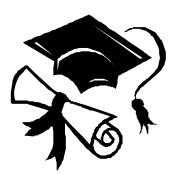

Aparecida Antonia Cristina Camolez

Orientador: Prof. Dr. Mário De Biasi

A relação do Homem com o meio ambiente em áreas urbanas é complexa e provoca grandes alterações não só na paisagem mas também na qualidade de vida da população que reside em regiões metropolitanas. A expansão da mancha urbana das regiões metropolitanas de São Paulo e da Baixada Santista têm se consolidado em direção às periferias dos municípios que as compõem. Em São Paulo, nos arredores da Represa Billings, área de mananciais, predomina uma ocupação de baixa renda, resultado do crescimento e do desenvolvimento da cidade de São Paulo, que empurrou para a periferia a população mais carente, obrigando-a a ocupar áreas distantes do centro. Já em Bertioga, a expansão urbana baseia-se principalmente no crescimento do turismo e das atividades econômicas afins, sendo este o município com maior taxa de crescimento demográfico do Estado de São Paulo. Apesar de diferir nos motivos da expansão urbana, essas duas regiões apresentam um problema em comum: o crescimento urbano sem planejamento, com degradação da cobertura vegetal natural, mesmo que esta esteja protegida por leis ambientais específicas. A interpretação de imagens de satélite de épocas diferentes (1992 e 2003), e a técnica do Modelo Linear de Mistura Espectral, foram utilizadas para a confecção de mapas de uso da terra que permitiram contabilizar o crescimento urbano e a redução da cobertura vegetal nas áreas de estudos e que foram utilizados para uma discussão sobre a ocupação urbana e a legislação ambiental aplicável nessas regiões. 


\section{Brasília: do projeto hegeliano à produção do espaço da reprodução capitalista}

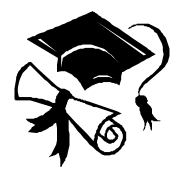

César Ricardo Simoni Santos

Orientador: Prof. Dra. Ana Fani

Alessandri Carlos

A concepção de espaço que pesa sobre o plano que deu origem à cidade de Brasília se identifica àquela de uma certa filosofia da história, no momento de sua realização, em seu fim. Esta filosofia de inclinação hegeliana está na base do pensamento que vai dar sustentação e legitimidade à formação do moderno Estado burocrático (burguês) no Brasil e, por sua vez, fundamentará também a concepção histórica que importa para a formação da moderna arquitetura e urbanismo brasileiros. Assim, como resultado da conjugação desses dois campos (Estado e urbanismo), Brasília representa, em sua construção, a realização de um espaço lógico e racional, que preconiza a finalização da história com a consagração de tal espaço juntamente com o Estado. Um novo momento da história sem história. Um espaço mais lógico que histórico. Neste momento, se opera uma substituição da história pela lógica no espaço de Brasília: a realização da razão sobre a Terra, o movimento apresentado pela filosofia hegeliana. Assim, esse espaço se apresenta para o poder e para a economia como um espaço destituído das inconveniências de um passado histórico, destruídas pela força desse projeto. Um espaço livrado de todas as formas e conteúdos que não se identificam com as condições de realização do Estado (hegemônico) e de reprodução do capitalismo a uma escala ampliada. A concepção de espaço que resulta daí é de um espaço "quase pura lógica" que serve à reprodução do Estado e do capitalismo. Brasília é uma cidade construída para hegemonia do Estado, diante da necessária absorção dos capitais excedentes e para a continuação do crescimento do capitalismo industrial brasileiro. Um gesto de acumulação primitiva que separa espaço e história. Os anos da década de 1950 são marcados pela consolidação do moderno capitalismo industrial brasileiro e do moderno Estado burocrático através da construção de Brasília.
Favela, que negócio é este?: um estudo sobre o projeto de urbanização da favela do Jaguaré no contexto dos negócios urbanos e de sua reprodução crítica

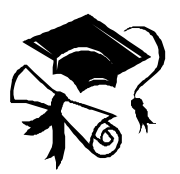

Flávia Elaine da Silva Martins

Orientador: Prof. Dra. Amélia Luisa Damiani

Esta pesquisa aborda, por meio do projeto de urbanização da favela do Jaguaré, a inserção das políticas de urbanização de favelas nos negócios urbanos, a partir da consideração da reprodução do capital em seus termos críticos.

\section{exeseres}

Este movimento segue desde as novas condições de negociação do espaço urbano, apresentadas nas Operações Urbanas, fundamentadas na relação de contrapartida e atualizadas em novos instrumentos de troca do espaço urbano, até o financiamento destes projetos por agências internacionais, configurando novos ritmos de execução das obras e de comprometimento dos orçamentos municipais e federais. Finalmente, por meio de uma prática espacial de pesquisa - a deriva - e tomando a vida cotidiana como plano de pesquisa, é possível abordar a movimentação de uma centralidade urbana, os desdobramentos espaciais implicados nesta nova centralidade e a inserção dos ritmos de financiamento no modo de vida dos moradores da favela. 


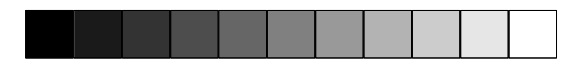

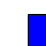

Teses de Doutorado e Dissertações de Mestrado Defendidas

\section{A representação espacial no estudo da paisagem e das variáveis ambientais em arqueologia \\ Jacqueline Freitas de Oliveira}

Orientador: Prof. Dr. Flávio Sammarco Rosa

Esta pesquisa pretende destacar a importância do mapeamento como elemento de apoio à pesquisa arqueológica, indo além de seu caráter ilustrativo e, demonstrar como a Cartografia, aliada às técnicas de Sistemas de Informações Geográficas, pode contribuir às análises ambientais em arqueologia. A intenção é apresentar a Cartografia como parte integrante da investigação arqueológica, explorando as ferramentas oferecidas pelo SIG e encarando o mapeamento como ponto de partida para o estudo dos sítios arqueológicos e da paisagem.A proposta é enfatizar a importância do registro espacial como forma de apreensão e compreensão do espaço e das variáveis ambientais.

$$
\text { extes es }
$$

\section{O espaço geográfico do oeste catarinense e sua cartografia ambiental}

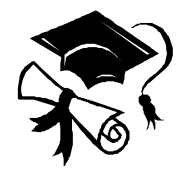

Liane Welter

Orientador: Prof. Dr. Marcelo Martinelli

O objetivo central do trabalho é congregar os componentes naturais e sociais que agem no ambiente da região Oeste Catarinense, tendo em vista uma cartografia ambiental.Para tanto, abordamos e representamos em mapa os elementos referentes a geologia, relevo, solos, vegetação, clima, uso da terra e cobertura do solo, rede de drenagem, divisão administrativa e rede viária. Uma visão de síntese, integrada e espacializada da realidade do ambiente regional foi obtida com a utilização de técnicas de geoprocessamento, que, dentre suas possibilidades permitiram a identificação de cinco unidades ambientais e suas subdivisões para o Oeste Catarinense.
A geografia do atrito: dialética espacial e violência em Campinas-SP

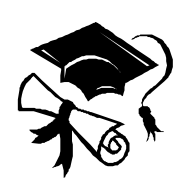

Lucas de Melo Melgaço

Orientador: Prof. Dr. Maria Adélia Aparecida de Souza

A presente dissertação tem como objetivo central promover uma discussão a respeito do diálogo entre a Geografia e o estudo da Violência. Porém, diferentemente da maioria das pesquisas feitas na área de violência urbana, as quais têm no método analítico o seu principal referencial teórico, procura-se, aqui, trazer uma reflexão dialética à questão. No atual período técnico-científico e informacional, torna-se impossível entender esta prática espacial denominada violência se a considerarmos apenas como um recorte analítico da realidade. É por este motivo que não pretendemos fazer uma "geografia da violência" ou, muito menos, uma "geografia do crime", e sim uma geografia dos usos do território e das suas relações com a temática do crime e da violência. Faz-se necessário, então, um método que entenda o espaço geográfico enquanto um todo em movimento, um sistema indissociável de objetos e ações (SANTOS, 1997c, 1998, 1999a). Nessa 
busca por uma compreensão das relações entre território e violência, o Geoprocessamento se mostrou uma ferramenta de fundamental importância, tanto por suas potencialidades, quanto por suas limitações enquanto instrumento de representação do espaço geográfico. Aliando a técnica do Geoprocessamento à profundidade do método dialético foi possível se perceber o potencial da Geografia enquanto modo de compreensão da violência e, mais amplamente, enquanto instrumento de planejamento territorial. Nesta reflexão, alguns conceitos e autores aparecem com contribuições fundamentais, dentre eles o de território usado (SANTOS et al. 2000a), solidariedades geográficas (SANTOS, 1994, 1998), cotidiano (CERTEAU, 1994), além das concepções de poder e violência trazidas por Hannah Arendt (1994). Conclui-se que a violência urbana é uma questão de caráter muito mais político que propriamente técnico, e que a violência em Campinas-SP é fruto dos usos corporativos do território e das escolhas históricas feitas por esta cidade e pela formação sócio-espacial na qual está inserida. Pôde-se ainda vislumbrar o quanto a Geografia pode se aproximar de uma ciência da ação.

\section{A convenção sobre biodiversidade e as comunidades locais na Bolívia}

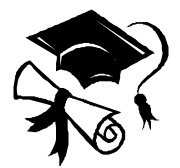

Maria Angela Comegna

Orientador: Prof. Dr. Wagner Costa Ribeiro

A exploração desenfreada de recursos naturais e o embate entre o meio ambiente e as demandas da sociedade tecnológica, geram tendências alarmantes. Uma delas diz respeito à perda da diversidade biológica e de comunidades locais e dos seus conhecimentos tradicionais. A Convenção sobre Biodiversidade (CB), parte da Ordem Ambiental Internacional declara o direito soberano dos países sobre sua biodiversidade. Ela também é o principal instrumento internacional a reconhecer a importância e a necessidade de proteção aos conhecimentos e práticas tradicionais associados aos recursos genéticos. Seu alcance vai além da conservação e utilização sustentável da biodiversidade, abrangendo o acesso aos recursos genéticos e a repartição justa e eqüitativa dos benefícios originados do seu uso. Neste debate insere-se a Bolívia, detentora de uma importante fonte de patrimônio genético do planeta. O país alia à diversidade biológica uma grande diversidade étnica e cultural baseada principalmente na variedade de recursos genéticos ofertados pela natureza, que possibilitam a sobrevivência das comunidades locais em seus vários ecossistemas. Assim, nosso principal objetivo no trabalho será a análise da incorporação dos princípios da Convenção sobre Biodiversidade na legislação da Bolívia e das suas repercussões nas comunidades locais do país.Para tanto, analisamos a Ordem Ambiental Internacional, a CB e a regulação dos conhecimentos tradicionais produzidos pelas comunidades locais da Bolívia. Os direitos das comunidades locais e a gestão dos recursos genéticos do país também serão contemplados, à luz das normativas regionais e nacionais relacionadas à proteção e distribuição de benefícios às referidas comunidades. Pudemos constatar que na Bolívia a questão da biodiversidade e dos conhecimentos tradicionais vem sendo incorporada à legislação nacional e às políticas públicas, sendo que o principal desafio a ser enfrentado pela Bolívia é a implementação de uma normativa que contemple os interesses dos diversos setores e comunidades do país, extremamente heterogêneo. Este trabalho busca colaborar para a interpretação da Ordem Ambiental Internacional. Desta forma, esperase contribuir para o desenvolvimento do conhecimento geográfico no que se refere às implicações locais dos tratados globais. 


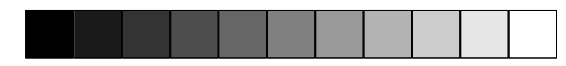

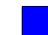

Teses de Doutorado e Dissertações de Mestrado Defendidas

\section{O lugar do lixo na cidade de São Paulo, a gestão territorial e a contribuição geográfica}

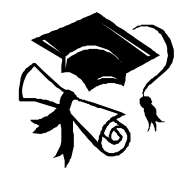

Otavio Cabrera de Léo

Orientador: Prof. Dr. Reinaldo Paul Pérez Machado

Contemplamos o manejo dos resíduos sólidos enquanto objeto de pesquisa geográfica, à medida que acreditamos na possibilidade da centralidade de tal objeto revelar a própria essência do estudo geográfico na correlação dos conceitos balizadores da interpretação sócioespacial, tais como, o lugar, a paisagem, o território, a região e a regionalização. Nossa proposta consiste fundamentalmente na abordagem do planejamento territorial, no âmbito do vislumbramento da contribuição geográfica que este pode conter. Não obstante, nosso propósito suscita em primeira instância, não negligenciar a própria definição do planejamento territorial.Em nosso presente estudo procuramos encontrar o "veio geográfico" no dimensionamento da demanda por localização de áreas para a destinação final dos resíduos sólidos gerados na Grande São Paulo, focando a problemática na capital metropolitana, com o intuito de revelar a concepção de gestão territorial envolvida, bem como o próprio teor geográfico intrínseco a esta concepção.Além do recurso da pesquisa historiográfica, trabalhamos através da cartografia tradicional e digital, do sensoriamento remoto e do processamento digital de imagens orbitais, portanto, com o geoprocessamento, para obtermos como resultado prático à pesquisa, o mapeamento das áreas dos aterros sanitários do Município de São Paulo, caracterizando suas superfícies de influência direta, bem como levantando as possíveis implicações sócio-ambientais nas respectivas localidades, fundamentalmente àquelas que se apresentam em estado crítico de manutenção quanto à qualidade do ambiente urbano adjacente

\section{eses es es}

\section{A pesca da manjuba (anchoviella lepidentostole) e o canal do Valo Grande: uma relação de (des)continuidades em Iguape-SP}

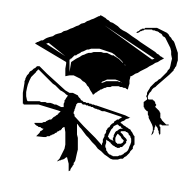

Rafaelle Rocha Souza Carneiro

Orientador: Prof. Dra. Léa Francesconi

O presente estudo procurou compreender como se efetua a pesca da manjuba em Iguape-SP e qual a sua relação com o canal do Valo Grande: quais as modificações sofridas pela atividade pesqueira no município, antes, durante e após a construção da barragem no dito canal, e como os pescadores passaram a se organizar após essa interferência no meio ambiente. Objetivou compreender o modo de vida do pescador, através dos seus saberes tradicionais, e corno esse modo de vida ainda resiste nos dias atuais, onde a tônica é pescar mais e mais, a fim de se obter uma renda maior. Enfim objetivou-se, mediante o diálogo entre teoria e conhecimento tradicional, mostrar como um pescador artesanal resiste num campo tão competitivo, como é a pesca da manjuba. 

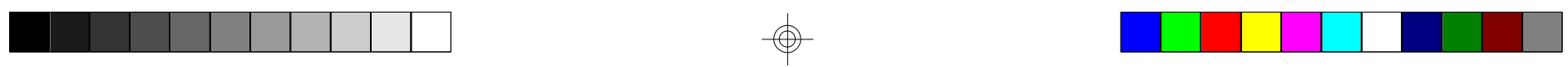

\section{Jerusalém: religião e soberania - uma disputa histórica}

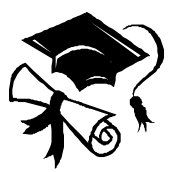

Roberto Akerman

Orientador: Prof. Dr. Francisco Capuano Scarlato

A cidade de Jerusalém se constitui na principal questão a ser negociada no conflito entre israelenses e palestinos. O seu valor simbólico nos âmbitos nacional e religioso tem impedido que Israel e Palestina, envolvidos neste conflito que tem raízes históricas e territoriais complexas cheguem a algum acordo em relação à soberania de Jerusalém. Este trabalho tem por objetivo analisar o porquê de ser Jerusalém o centro nevrálgico das relações conflituosas de muçulmanos palestinos e judeus israelenses e abordar a dimensão histórica que tem desempenhado Jerusalém na construção do processo de identidade nacional tanto de palestinos quanto de israelenses, bem como as articulações existentes entre o sagrado e o nacional que se dão em seu território.Através da análise territorial, histórica e política de uma cidade que abriga locais sagrados dotados de simbolismos nacionais antagônicos, tem-se na questão da soberania de Jerusalém o principal obstáculo a um acordo de paz entre israelenses e palestinos.

$$
\text { 2estes }
$$

\section{Paisagem sonora do espaço migrante: a mobilidade e a percepção do processo migratório entre o sertão do Moro da Garça(MG) e a Metrópole de São Paulo(SP)}

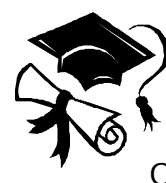

Rodrigo Passos Felicissimo

Orientador: Prof. Dr. Heinz Dieter Heidemann

Esta pesquisa analisa a paisagem sonora do migrante proveniente do município do Morro da Garça, no Estado de Minas Gerais. A intenção é a de registrar os sons característicos das paisagens sonoras do sertão mineiro em relação ao som dissonante da metrópole de São Paulo identificado através da memória e percepção dos migrantes do Morro da Garça. O estudo destaca aspectos da formação das redes sociais deste migrante na metrópole de São Paulo. Este tema, multidisciplinar, aborda uma nova forma de observação e análise do objeto de estudo, na geografia humana. O registro e a escuta da paisagem sonora revelam os agentes formadores constituintes da paisagem, sendo esta observada a partir das percepções e indagações a respeito dos sons do ambiente e da memória da comunidade morro-garcense. O estudo dos migrantes naturais desta região do cerrado brasileiro mostra um contexto, no qual eles estão inseridos na metrópole de São Paulo e, ao mesmo tempo, apresenta apontamentos relevantes a respeito dos fatores condicionantes que os levaram a migrar para o centro urbano. Por outro lado, destacam-se as razões e indicações que levaram um outro segmento de suas famílias, naturais também da região do Morro da Garça, a não migrarem.Em continuidade a esta pesquisa, o material coletado (entrevistas, ensaio fotográfico e registro das paisagens sonoras), poderá servir como base didática, no ensino fundamental e médio, para a ampliação do debate sobre as características culturais próprias da comunidade morro-garcense, evidenciando o imaginário sonoro que produz o sertão mineiro, também encontrado na metrópole de São Paulo.

$$
\text { eses eses }
$$




\section{Os loteamentos clandestinos no distrito do Jaraguá (SP): moradia e especulação}

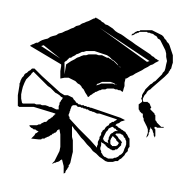

Sandra de Castro Pereira

Orientador: Prof . Dra. Glória da Anunciação Alves

A produção e a reprodução dos espaços periféricos da cidade de São Paulo são organizadas e realizadas dentro da lógica capitalista, caracterizada por uma permanente especulação imobiliária fortalecida pelo déficit habitacional e pela necessidade de moradia, bem como pelo sonho da casa própria. As escassas políticas públicas de habitação voltadas para as classes menos favorecidas, juntamente com o oportunismo de algumas pessoas, geram uma ocupação periférica marcada pela presença de loteamentos clandestinos e irregulares, como o que acontece no Distrito do Jaraguá, região noroeste da cidade de São Paulo. Nesse distrito, destacase nessa atividade, a Associação dos Trabalhadores Sem Terra de São Paulo (ATSTSP), coordenada por um atual vereador da mesma cidade e que deve em grande parte, sua eleição ao cargo executivo, aos associados da Associação, que depositaram seus votos como agradecimento, por ter conseguido comprar um lote, ou por ter a esperança de consegui-lo. Quando o Estado não cumpre seu compromisso em relação à habitação, abre um precedente para a formação de associações que fazem uso da necessidade da população para conseguir vantagens políticas e econômicas.

\section{ceseres ex}

\section{Águas transfronteiriças superficiais: o caso da bacia do Rio Danúbio}

\section{Sinval Neves Santos}

\section{Orientador: Prof. Dr. Wagner Costa Ribeiro}

Acompanhamos, nas últimas décadas, a temática ambiental se transformar em um dos principais desafios para a humanidade. Sua dimensão transnacional, alcançada quando os limites naturais não coincidem com os limites políticos, potencializa a complexidade da problemática. Em conseqüência, temas como sustentabilidade e segurança ambiental passam a ocupar posições de destaque na agenda internacional, fato que demanda novas interpretações da concepção clássica de soberania.A questão das águas transfronteiriças superficiais - águas que escoam sobre bacias hidrográficas internacionais - representa uma materialização dos desafios mencionados acima, sobretudo porque esses recursos correspondem a maior parcela da água doce superficial e estão sujeitos a severas ameaças. Entre elas: o consumo excessivo de estoques hídricos limitados, que vem provocando uma crise de escassez; além dos antagonismos inerentes à necessidade de compartilhamento desses recursos, que motivam concorrências entre distintos interesses nacionais. Em função disso, surgem preocupações e questionamentos referentes à capacidade de a água gerar, ou acirrar, tensões internacionais. Partindo das intrínsecas relações entre território e política, essa dissertação identifica as variáveis ligadas ao potencial conflitivo/cooperativo das águas transfronteiriças superficiais. Em meio a essa tarefa, temos oportunidade de discutir como os novos temas da agenda internacional incidem nessa questão. A análise da bacia do rio Danúbio, como estudo de caso, comprova que as águas transfronteiriças superficiais podem deteriorar as relações entre países e que circunstâncias geográficas e políticas são cruciais na definição dos interesses dos Estados e, conseqüentemente, na qualidade do desfecho da questão. 


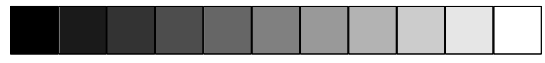

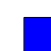

266 - GEOUSP - Espaço e Tempo, São Paulo, № 19, 2006

\section{Vila Guilherme e Vila Leopoldina: um estudo sobre duas regiões da cidade de São Paulo}

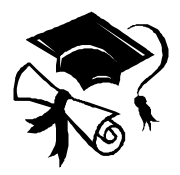

Tereza Cristina Vespoli

Orientador: Prof. Dr. Reinaldo Paul Pérez Machado

Este trabalho buscou analisar os elementos e agentes presentes na estruturação físicoespacial da Vila Guilherme e Vila Leopoldina, cujo território ocupa parte do que foram as áreas de várzeas dos rios Tietê e Pinheiros. As duas áreas de pesquisa caracterizaram-se ao longo do século $X X$, inicialmente como espaços rurais ou de exploração mineral e através do processos urbano-industriais instalados na cidade, transformaram-se em áreas fabris e de moradia unifamiliar predominantemente popular, indicando mais recentemente uma reestruturação dessa configuração através de novas destinações e ocupações dos espaços ali existentes, como é possível verificar pelas ocorrências em curso nas áreas pesquisadas. Tal fato evidencia, no plano local, a transformação que São Paulo apresentou a partir da década de 1980 em relação às localizações industriais, de serviços e de moradia, permitindo uma reflexão sobre os possíveis padrões urbanos e ambientais relacionados a esses novos cenários.

\section{eseres es}

\section{Imigração japonesa no estado de São Paulo,} 1908-1941

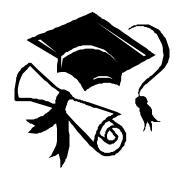

Walter Kudo Maejima

Orientador: Prof. Dr. Flávio Sammarco Rosa
Este trabalho foi elaborado com o intuito de analisar o processo de imigração japonesa no Estado de São Paulo, entre 1908 e 1941. Procuramos contextualizar os movimentos migratórios pela análise dos fatores que intensificaram tal processo, no âmbito mundial e nacional, além da caracterização dos principais fluxos populacionais e a sua mobilidade social e espacial, ao longo do período de abrangência do estudo.

\section{O ensino da cartografia nas séries iniciais do ensino fundamental: um estudo sobre metodologia e conteúdos na prática docente}

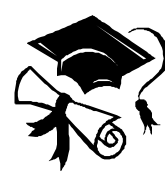

Waldiney Gomes de Aguiar

Orientador: Prof. Dra. Sonia Maria Vanzella Castellar

Estudar Geografia deve ser uma prática contínua na vida, dos alunos a partir do momento em que descobre, que através dela, podem entender o mundo e as relações que constituem o cotidiano. Ainda na faculdade, os acadêmicos ao trabalhar os conteúdos percebem que vários dos conteúdos trabalhados na graduação não são articulados com os trabalhados no Ensino Fundamental. Ao deparar com essa situação o acadêmico tem a impressão que não aprendeu nada A partir disso, percebese que a Geografia poderia ser trabalhada de forma diferente ainda na faculdade no sentido de verificar os conteúdos que fazem parte da grade curricular no Ensino Fundamental para ser desenvolvido na academia estratégia que contribuiria para minimizar os problemas relacionados a conteúdos e metodologia que os 

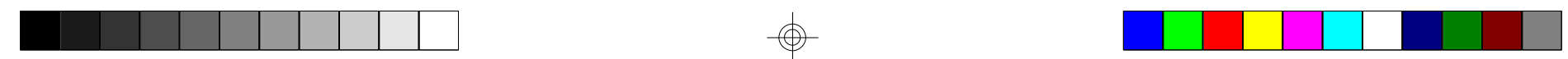

Teses de Doutorado e Dissertações de Mestrado Defendidas

(Novembro de 2005 a Abril de 2006), pp. 245 - 270

acadêmicos poderão encontrar na escola . É a partir de problemas encontrado por nós enquanto professor da $5^{\underline{a}}$ série e ao mesmo tempo no curso de licenciatura em geografia que surge a idéia de pesquisar, especificamente o ensino da cartografia na $4 \underline{a}$ série, pois entendemos que ai está um "nó". Alem do professor da $4 \underline{a}$ série não ter uma formação específica para trabalhar os conteúdos, da mesma forma o professor da 5 a série não consegue articular conteúdos e metodologia capaz de garantir a aprendizagem dos alunos egressos da 4ạ série. Isso se dá também por meio do distanciamento entre a faculdade e a escola conforme comentamos acima.Neste sentido, nossa pesquisa pretende levantar questões relacionadas à cartografia nas séries iniciais para verificarmos como vem sendo desenvolvidos o ensino e aprendizagem e contribuirmos para o processo, visando o sucesso dos alunos na escola.

\section{Os bairros como instância territorial local: contribuição metodológica para o caso de São Paulo}

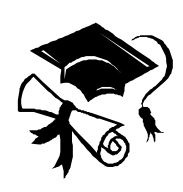

José Donizete Cazollato

Orientador: Prof. Dr. Reinaldo Paul Pérez Machado

Esta dissertação tem como tema central os bairros das grandes cidades, tomando como caso o Município de São Paulo, onde, apesar de existirem como espaço das relações cotidianas, locais, os bairros não são reconhecidos nem delimitados como unidades operativas pelo poder público. Uma nova metodologia é apresentada com vistas à sua adequada delimitação e sua oficialização como unidades da divisão territorial do município, esperandose, assim, que os bairros possam operar como instrumentos de apreensão da realidade, de gestão territorial e de exercício da cidadania. Embasada no conceito geográfico que define território como a porção espacial denominada, apropriada e delimitada, a proposta considera o Município de São Paulo sob três enfoques: o substrato físico-urbano, as estruturas territoriais e de lugares e a visão do cidadão. Elabora um padrão de bairro - que se constitui no pilar central da metodologia - e sugere as etapas seguintes, onde o inventário toponímico tem grande destaque. Como ensaio de aplicação, a proposta é testada em dois distritos: Lapa e Lajeado.

\section{A convenção de basiléia e o destino dos resíduos industriais no Brasil}

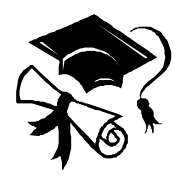

Luciana Aparecida Iotti Ziglio

Orientador: Prof. Dr. Wagner Costa Ribeiro

A Convenção de Basiléia sobre o Controle de Movimentos Transfronteiriços de Resíduos Perigosos e seu Depósito trata-se de um acordo que define mecanismos de organização dos movimentos transfronteiriços de resíduos sólidos e líquidos perigosos e sua disposição final. Os resíduos perigosos são materiais descartados que podem colocar em risco a segurança da vida.A Convenção para atingir seu propósito de existência permite a concessão prévia e explícita de importação e exportação dos resíduos autorizados entre os países que dela participam, de modo a evitar o tráfico ilícito. $\mathrm{O}$ Brasil através do Decreto número 875 de 19 de julho de 1993 confirmou sua permanência como integrante da convenção, internalizando assim o documento no país. A partir de então, todo o comércio internacional de resíduos perigosos entre o Brasil e o exterior passou a ser regulamentado. 

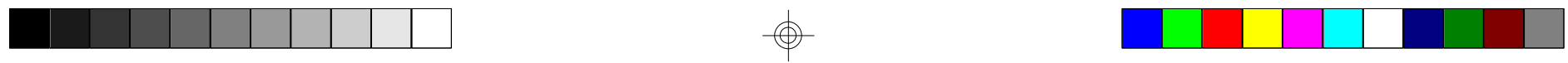

268 - GEOUSP - Espaço e Tempo, São Paulo, № 19, 2006

Os resíduos industriais, considerados perigosos constituem, no Brasil, motivo de preocupação das autoridades e órgãos ambientais, seja devido às quantidades que vem sendo geradas, principalmente como resultado da elevada concentração industrial em algumas regiões do país, seja pela carência de instalações e locais adequados para o tratamento e destino final.Descrever e discutir as dimensões deste documento e ao mesmo tempo demonstrar sua repercussão na realidade brasileira será o propósito desta dissertação.

\section{Inferências geográficas: o processo analítico hierárquico e o modelo booleano ponderativo aplicados no diagnóstico da estabilidade ambiental do município de itirapina}

Marcos Roberto Martines

Orientador: Prof. Dr. Reinaldo Paul Pérez Machado

Este trabalho teve como objetivo fundamental o estudo comparativo da representação cartográfica da estabilidade ambiental no município de Itirapina, São Paulo, utilizando dois diferentes métodos de inferência geográfica: o Booleano Ponderativo e o Processo Analítico Hierárquico. Para isso foram considerados os temas: Geologia, Pedologia, Declividade e Uso da Terra e Cobertura Vegetal. Os resultados, obtidos mediante a utilização de técnicas de geoprocessamento, permitiram diferenciar os modelos em função dos procedimentos operacionais adotados, mostrando e identificando das áreas em estabilidade e instabilidade ambiental à erosão em função dos fatores acima considerados.

\section{exes exses}

Da balcanização à "balcanização"

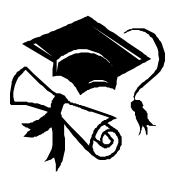

Moacir Nunes e Silva

Orientador: Prof. Dr. André Roberto Martin

Segundo Norberto Bobbio, Balcanização corresponde a um termo para designar uma divisão de entidade continental, sub-continental ou regional em unidades politicamente separadas ou hostis entre si. O conceito está associado à região dos Bálcãs no período das guerras balcânicas, entre 1912 e 1913, fragmentando nações em unidades políticas distintas, prevalecendo as diretrizes do processo de relacionamento entre Estados.Contudo, o título desta pesquisa como reflexo do trabalho, atribui ao conceito uma dupla conotação. Assim, Balcanização, sem aspas, significa a fragmentação em si, porém enaltecendo processos anteriores, e, principalmente posteriores às Guerras Balcânicas, identificando personagens e processos no movimento de tal esfacelamento e procurando relativizar algumas verdades, tidas como absolutas, como a correspondente aos turcos islâmicos como sanguinários e ao da igreja católica como libertária. 0 segundo termo Balcanização significa a visão sobre os Bálcãs, um espelho no sentido de espetáculo, por isso as aspas, denotando a estereotipia atribuída à análise de tal região; neste sentido, o trabalho de Maria Todorova - Imagining the Balkans foi uma importante referência na perspectiva desmistificadora da expressão, cuja conotação é excessivamente pejorativa, particularmente na dimensão do território, outrora denominado lugoslávia, objeto de estudo desta obra.Delimitando a perspectiva analisada acima ao caso iugoslavo e engendrando o local, o regional e o mundial, o título, como reflexo do texto, busca selar os dois sentidos, o objeto e sua imagem, compreendendo-os, no limite do possível, em sua diversidade totalizante de sentidos, por isso: Da Balcanização à "Balcanização". 


\section{Esboço inicial da climatologia na geografia da faculdade de filosofia, letras e ciências humanas da universidade de São Paulo}

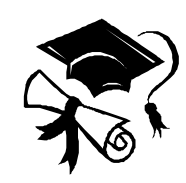

Romeu Antônio de Araujo

Orientador: Prof. Dr. Tarik Rezende de Azevedo

Este ensaio tem o objetivo de contribuir para o estudo da criação da Faculdade de Filosofia, Ciências e Letras, fator determinante para a fundação da Universidade de São Paulo, em janeiro de 1934, e a participação dos Professores europeus que, como Lentes, foram convidados a dar os contornos iniciais para as diversas áreas da recém criada Faculdade. Nos anos seguintes outros eminentes pensadores, ajudaram a consolidar o projeto da constituição da Universidade. As pesquisas foram centradas na organização e desenvolvimento dos cursos de Geografia, realizados por professores franceses, cuja obra continuou através dos alunos por eles orientados, que se tornaram Docentes na própria Universidade, e formaram os membros da chamada Escola Paulista de Geografia, destacando-se aqueles cuja dedicação foi maior ao estudo da Climatologia. Não apenas a chamada Escola Paulista de Geografia, mas a Faculdade de Filosofia, Ciências e Letras e a Universidade de São Paulo como um todo, formaram gerações de profissionais em todas as áreas do conhecimento, muitos deles dedicaram-se ao Magistério, tornando-se referenciais na construção da História da Educação em todo o Brasil.Os professores que participaram dessa realização, enfrentando dificuldades de toda sorte, uma verdadeira "Epopéia", pertencem ao rol dos mais eminentes e relembrados nomes da Geografia. A célebre "Escola Francesa de Geografia", teve nos primeiros orientados, os continuadores da obra realizada pelos professores que iniciaram os estudos da Geografia e, portanto, pioneiros na pesquisa dessa ciência no Brasil.

\section{ESe ex}

\section{Unidades ecodinâmicas: análise da fragilidade ambiental do Parque Estadual do Morro do Diabo e Entorno, Teodoro Sampaio/SP}

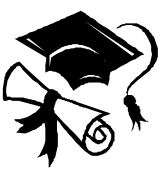

Rosangela do Amaral

Orientador: Prof. Dr. Jurandyr Luciano Sanches Ross

Localizado no extremo Oeste do Estado de São Paulo, o Pontal do Paranapanema é uma área caracterizada por pastagens extensivas em relevo de colinas amplas com intensos processos erosivos. O desmatamento gerado pela ocupação desordenada e irregular, que se deu com a apropriação irregular de parte das terras da região e a construção da Estrada de Ferro Sorocabana no início do século passado, acabou por agravar os processos erosivos. 0 objetivo desta pesquisa é analisar as fragilidades ambientais naturais perante as intervenções antrópicas na Bacia do Ribeirão Bonito e entorno, incluindo-se o Parque Estadual do Morro do Diabo em toda a sua extensão, no município de Teodoro Sampaio. Nessa bacia ocorrem predominantemente três tipos de uso da terra: a área restrita ao Parque Estadual do Morro do Diabo, destinada à preservação da fauna e flora, as pastagens e as agriculturas diversificadas. A fragilidade ambiental pode ocorrer por fatores naturais, devido a uma combinação de características climáticas, pedológicas e geomorfológicas ou devido ao fator antrópico, representado pelo uso da terra.Os processos erosivos na área de estudo são desencadeados primeiramente pela combinação entre o tipo de solo da região, com composição granulométrica predominante de cerca de $80 \%$ de areia, e o uso da terra implantado, basicamente a pastagem e as 

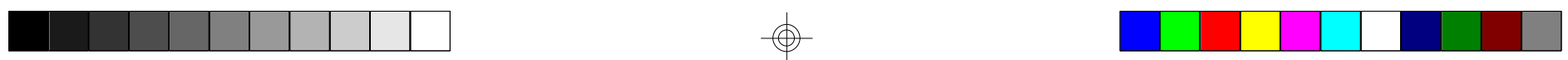

agriculturas. Para análise da representatividade dos dados obtidos por mapeamento, feito a partir de fontes secundárias e levantamentos de campo, foram executados experimentos de infiltração e de resistência dos solos à erosão, além de coleta de amostras de solo para granulometria e de matéria orgânica. Esses ensaios foram realizados em seis pontos na área da Bacia do Ribeirão Bonito em alta, média e baixa vertentes.Para a análise, foi utilizado o Sistema de Informações Geográficas (SIG) SPRING 3.6, desenvolvido pelo INPE, que possibilitou a confecção da carta síntese, Carta das Unidades Ecodinâmicas de Instabilidade Potencial e Emergente, a partir da correlação de dados geomorfológicos, pedológicos e de uso da terra.

\section{Les Les}

Delimitação de unidades climáticas locais no parque nacional cavernas do peruaçu

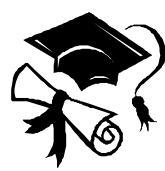

Sérgio Serafini Júnior

Orientador: Prof. Dr. José Bueno Conti

Localizado na porção Norte de Minas Gerais, o Parque Nacional Cavernas do Peruaçu, é considerado um dos mais importantes patrimônios arqueológicos brasileiros, onde um grande número de sítios arqueológicos está concentrado fazendo do local uma área privilegiada para pesquisas nesta área.Além da arqueologia, também é grande o número de trabalhos voltados para a geologia e biologia, uma vez que esta Unidade de Conservação encontra-se numa região cárstica e de transição entre os Biomas da Caatinga e do Cerrado.Com base na pesquisa bibliográfica realizada, foi observado que a predileção por estes temas de pesquisa, colocou os estudos sobre o clima do Parque Nacional Cavernas do Peruaçu em segundo plano. A partir disso, a proposta deste trabalho foi realizar um estudo climático desta Unidade de Conservação na escala local a partir do entendimento das diferentes paisagens ali presentes que foram agrupadas segundo o critério de homogeneidade fisionômica e enquadradas nas escalas dos geossistemas e geofácies. Assim, considerando os dados de temperatura e umidade relativa registrados na área de estudo nos meses de julho de 2003 e janeiro de 2004, juntamente com a caracterização das unidades de paisagens ali identificadas, foram propostas três unidades climáticas na escala local que se sobrepuseram aos limites dos Geossistemas identificados. 
